N.Sh. Botirova

Tashkent Islamic university, A senior teacher of the department World economy and international economical relations
p-ISSN: 2308-4944 (print) e-ISSN: 2409-0085 (online)

Year: 2017 Issue: 08 Volume: 52

Published: $10.08 .2017 \quad$ http://T-Science.org

SECTION 31. Economic research, finance, innovation, risk management

\title{
THE INDUSTRIALIZATION PROCESS AND ITS PERSPECTIVES IN THE REPUBLIC OF UZBEKISTAN
}

Abstract: The article deals with the process of industrialization of the Republic of Uzbekistan and its prospects. There is reviewed the issues of export-oriented industries on the basis of import-substituting industrialization and the stages of its development. The main factors of industrial development in the past period are considered. Finally, the ability to reflect the efficient implementation of foreign economic relations in the country's industrialization process is analyzed.

Key words: Industry, social security, technical development, light industry, export, import, investment, diversification, production efficiency.

Language: English

Citation: Botirova NS (2017) THE INDUSTRIALIZATION PROCESS AND ITS PERSPECTIVES IN THE REPUBLIC OF UZBEKISTAN. ISJ Theoretical \& Applied Science, 08 (52): 12-18.

Soi: http://s-o-i.org/1.1/TAS-08-52-3 Doi: crossef https://dx.doi.org/10.15863/TAS.2017.08.52.3

\section{Introduction}

Having a high industrial level is a reason of the stable economic basis, abundant life for citizens, scientific and technical development in any country. Realization of the industrialization processes has a special importance in the solution of the economic problems. The industrialization process is one of the main criterions of the economic development. The industrial level of a country indicates how much it is developed. According to our first President I.A. Karimov's saying that "Realization of high technologic projects directed to develop the total basis of industry which ensures our economic independence and to produce finished goods on the basis of rich raw materials and resources is an important task for our country"[1,5], it was paid a special attention to the industrialization process in our country. This process was carried out according to the macroeconomic condition and formation of market relations, description of component changes and strategy of industrialization. Its first stage included the period of 1991-1995 and it was described as that in which measures for saving of the existent industrial capacity was realized. The second stage was carried out in 1995-2000 for development of the important fields of industry and realization of the strategy of industrialization, which replaces import on a large scale, multiplying investments into the fields of industry and, especially, for increase of the capital deposits in sectors of motor, light, chemistry and food industries. In the third stage of industrialization (after 2000) the main attention was paid to the formation and development of industrial fields directed to export on the basis of industrialization that replaces import.

\section{Materials and Methods}

Creation of new technologies and innovations is considered as a new step in industrialization and this process demands many cash resources. In modern economy, the problem of industrial production depends on the changes that occur in the world economy, and besides, at that it is very important to take into consideration objective changes in the geopolitical and geo-economic conditions of the world and benefits of certain countries in foreign economic relations as well as benefits of the national and transnational companies and the national factories which are taking active part in the international industrial cooperation. At the same time, it is necessary to take into account scientific and technical opportunities of each sector and to pay a special attention to the production of goods which can have their own position in the world market.

In the period after 2000, a special attention was paid to the development of textile and light industries. The purpose of that is a formation of a single technical and financial branch of this industry 


\begin{tabular}{|c|c|c|c|c|c|c|}
\hline Impact Factor: & $\begin{array}{l}\text { ISRA (India) } \\
\text { ISI (Dubai, UAE } \\
\text { GIF (Australia) } \\
\text { JIF }\end{array}$ & $\begin{array}{r}=1.344 \\
=0.829 \\
=0.564 \\
=1.500\end{array}$ & $\begin{array}{l}\text { SIS (USA) } \\
\text { PИНЦ (Russia) } \\
\text { ESJI (KZ) } \\
\text { SJIF (Morocco) }\end{array}$ & $\begin{array}{l}=0.912 \\
=0.234 \\
=3.860 \\
=\mathbf{2 . 0 3 1}\end{array}$ & $\begin{array}{l}\text { ICV (Poland) } \\
\text { PIF (India) } \\
\text { IBI (India) }\end{array}$ & $\begin{array}{l}=6.630 \\
=1.940 \\
=4.260\end{array}$ \\
\hline
\end{tabular}

as well as an increase its part in the gross domestic product. To achieve this purpose, a special attention was paid to adoption of a concerted investment policy in the field and involving of foreign investments directly as well as to realization of modern industrial technologies and modernization of companies and equipment of them with technics for productions of goods intended for export. Especially, deepening of economic reform processes and formation of joint-stock companies on a large scale, taking of a control over acceleration of the qualitative component changing processes and reproduction of a cotton fiber, equipment of companies with necessary materials and technical resources and development of social aspects of the formation of needs and necessity of the population as well as organization of manufacturing of public consumption goods were carried out in the sector.

The part of industry in GDP is also being increased due to these actions.

The role of industry in the national economy $[2,111]$

Table 1

\begin{tabular}{|c|c|c|c|c|c|c|c|c|c|c|c|c|c|}
\hline & 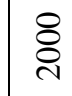 & 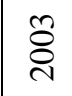 & $\underset{\sim}{\stackrel{\overbrace{}}{8}}$ & ঠ্ণ & 홍 & $\underset{\sim}{\infty}$ & 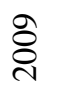 & $\stackrel{\circ}{\stackrel{ }{\sim}}$ & $\overline{\bar{D}}$ & 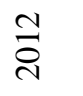 & $\stackrel{m}{\stackrel{n}{\sim}}$ & $\underset{\sim}{\stackrel{+}{\sim}}$ & 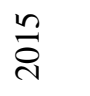 \\
\hline $\begin{array}{l}\text { The share of } \\
\text { industry in } \\
\text { GDP, \% }\end{array}$ & 4,2 & 5,8 & 21,1 & 21,8 & 21 & 22,3 & 23,6 & 23,9 & 24,1 & 24,0 & 24,2 & 24,1 & 33,5 \\
\hline
\end{tabular}

Nevertheless the part of industry in GDP was decreased in the intervening years, but it can be observed that its part in GDP was increased in general (table 1). Although the part of industry in GDP was not changed in 1998-2000, its part in GDP has begun to increase year by year since 2003. This indicator made up $17,5 \%$ in 2004 and it could increase more than $20 \%$ from 2005. Due to many attempts done for realization of component change in industry and modernization of its branches, involving of investments for implementation of projects on technic and technological upgrade, the part of industry in GDP is being increased year by year. In 2014, investment into industry was increased up to
$16,3 \%$ than that of $2013.36,3 \%$ of all involving investments was intended for industry. (This indicator made up $32,6 \%$ in $2005,30,4 \%$ in 2010 , $33,8 \%$ in $2011,34,2 \%$ in 2012 and $34,2 \%$ in 2013). In particular, $67,1 \%$ of investments was intended for the formation of new industrial production forces in 2015. In turn, it enabled to complete building of 158 big industrial objects which costs 7 billion 400 million dollar and put them into operation in 2015 . As a result of it, the part of industry in GDP made up $33,5 \%$ in 2015 [3,2]. But the part of industry in the whole employment was not changed in the last 10 years.

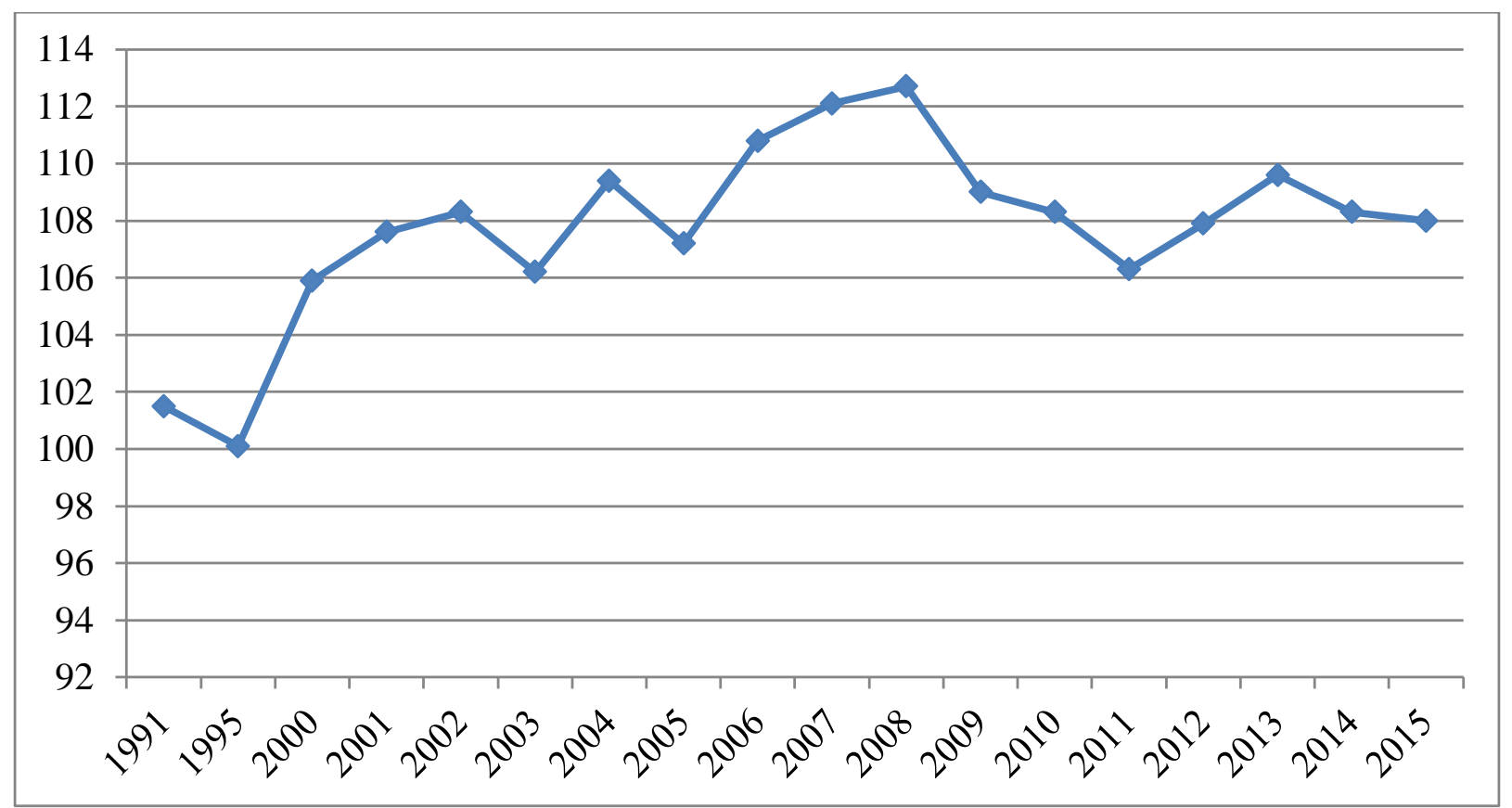

Figure 1 - Industrial production growth compared to last year $(\%)[4,12]$ 


\begin{tabular}{|c|c|c|c|c|c|c|}
\hline Impact Factor: & $\begin{array}{l}\text { ISRA (India) } \\
\text { ISI (Dubai, UAE } \\
\text { GIF (Australia) } \\
\text { JIF }\end{array}$ & $\begin{array}{r}=1.344 \\
=0.829 \\
=0.564 \\
=1.500\end{array}$ & $\begin{array}{l}\text { SIS (USA) } \\
\text { PИНЦ (Russia) } \\
\text { ESJI (KZ) } \\
\text { SJIF (Morocco) }\end{array}$ & $\begin{array}{l}=0.912 \\
=\mathbf{0 . 2 3 4} \\
=\mathbf{3 . 8 6 0} \\
=\mathbf{2 . 0 3 1}\end{array}$ & $\begin{array}{l}\text { ICV (Poland) } \\
\text { PIF (India) } \\
\text { IBI (India) }\end{array}$ & $\begin{array}{l}=6.630 \\
=1.940 \\
=4.260\end{array}$ \\
\hline
\end{tabular}

Between 2000 and 2014, the average annual additional growth rate of industrial production volume made up $8,6 \%$ (table 2). New types of many goods were created in the industrial companies.

Industrial production volume is changing dynamically in the large fields of the national industry in the subsequent period. Of course, these changes are considered as a result of reforms carried out in the fields of industry and conjectural changes in the component policy, domestic and international market.

Table 2

The dynamics of the index of industrial production compared to last year $\%[5,50 ; 2,113]$

\begin{tabular}{|c|c|c|c|c|c|c|c|c|c|c|c|}
\hline & $\overline{8}$ & 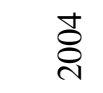 & $\stackrel{\overbrace{}}{8}$ & 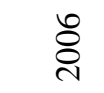 & 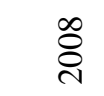 & 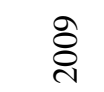 & $\stackrel{\circ}{\circ}$ & $\overline{\widetilde{N}}$ & $\stackrel{\text { ก }}{\stackrel{2}{1}}$ & $\stackrel{m}{\stackrel{N}{0}}$ & $\stackrel{ \pm}{\stackrel{N}{0}}$ \\
\hline GDP & 104,2 & 107,7 & 107,0 & 107,3 & 109,0 & 108,1 & 108,5 & 108,3 & 108,2 & 108 & 108,1 \\
\hline industry & 107,6 & 109,4 & 107,2 & 110,8 & 112,7 & 109 & 108,3 & 106,3 & 107,9 & 109,6 & 108,3 \\
\hline electro energy & 95,8 & 99,1 & 97,8 & 106,4 & 97,7 & 101,2 & 104,5 & 101,0 & 101,8 & 101,3 & 102,2 \\
\hline fuel & 96,4 & 106 & 99,1 & 105,1 & 125,9 & 110,3 & 103,5 & 100,3 & 105,5 & 101,5 & 98,1 \\
\hline $\begin{array}{l}\text { heavy } \\
\text { metallurgy }\end{array}$ & 110,6 & 131,6 & 105,3 & 111,6 & 105,4 & 108,4 & 105,8 & 106,3 & 107,2 & 102,8 & 116,5 \\
\hline $\begin{array}{l}\text { light } \\
\text { metallurgy }\end{array}$ & 101,8 & 104,9 & 97,6 & 99,2 & 94,9 & 102,6 & 99,1 & 102,4 & 102,7 & 103,5 & 101,7 \\
\hline $\begin{array}{l}\text { Chemistry and } \\
\text { oil chemistry }\end{array}$ & 106,8 & 103,3 & 108,1 & 117,1 & 108,2 & 111 & 115,4 & 107,9 & 111,9 & 104,1 & 108,9 \\
\hline $\begin{array}{l}\text { Automobile } \\
\text { industry }\end{array}$ & 124,8 & 132,1 & 131,1 & 124,2 & 124,2 & 117,4 & 111,6 & 112,2 & 116,3 & 124,2 & 113,5 \\
\hline $\begin{array}{l}\text { Wood and } \\
\text { paper industry }\end{array}$ & 108,6 & 119,1 & 125,7 & 122,7 & 128,9 & 119,1 & 107,0 & 107,1 & 110,1 & 123,4 & - \\
\hline $\begin{array}{l}\text { Construction } \\
\text { materials }\end{array}$ & 105,9 & 112,3 & 110,4 & 114,9 & 111,6 & 108,7 & 108,7 & 111,9 & 113,6 & 115,6 & 110,7 \\
\hline Light industry & 112,4 & 106,4 & 111,9 & 108 & 105,6 & 106 & 117,3 & 104,7 & 112,9 & 111,9 & 116,1 \\
\hline Food industry & 109,4 & 104,4 & 111,8 & 130,2 & 126,2 & 108,2 & 113,1 & 113,1 & 106,7 & 109,3 & 107,6 \\
\hline
\end{tabular}

Industrial sector is considered as a field in which the rate of industrial production is grown very fast. Light, food, motor, metal recycling, chemistry, ferrous and nonferrous metallurgy industries are grown very fast. Production of industrial goods was increased 2,3 times in 2005-2014 (table 2). The coefficient of diversification (production of various goods) was grown 2 times. In 2005-2014, the average additional growth rate in the fields of industry made up different percentage. In particular, it made up $1,6 \%$ in power industry, $5,9 \%$ in fuel industry, $8,0 \%$ in ferrous metallurgy, $0,5 \%$ in nonferrous metallurgy, $11,2 \%$ in chemistry and oil industries, $20,4 \%$ in motor and metal recycling industries, $11,7 \%$ in building materials industry, $9 \%$ in woodworking and paperwork industries, $10,2 \%$ in light industry, $14,3 \%$ in food industry. In general, the average annual additional growth rate of industrial production volume made up $8,1 \%$ in this period. In subsequent years, the main fields of our economy such as motor, chemistry and oil, food, building materials industries, pharmaceutical and furniture industry were grown with high rates. Adoption of new technologies in the industrial sector and building of new companies indicates that labor productivity was grown in this field. Acceleration of the modernization processes, technic and technological upgrade, and diversification of production have led to the realization of qualitative component changes in industry. The main directions of industrial policy were directed at the growth of competitive ability as well as at modernization and diversification of the industrial production. Some measures carried out have led to the growth of the qualitative index in the 


\begin{tabular}{|c|c|c|c|c|c|c|}
\hline Impact Factor: & $\begin{array}{l}\text { ISRA (India) } \\
\text { ISI (Dubai, UAE } \\
\text { GIF (Australia) } \\
\text { JIF }\end{array}$ & $\begin{array}{r}=1.344 \\
=0.829 \\
=0.564 \\
=1.500\end{array}$ & $\begin{array}{l}\text { SIS (USA) } \\
\text { PИНЦ (Russia) } \\
\text { ESJI (KZ) } \\
\text { SJIF (Morocco) }\end{array}$ & $\begin{array}{l}=0.912 \\
=0.234 \\
=3.860 \\
=\mathbf{2 . 0 3 1}\end{array}$ & $\begin{array}{l}\text { ICV (Poland) } \\
\text { PIF (India) } \\
\text { IBI (India) }\end{array}$ & $\begin{array}{l}=6.630 \\
=1.940 \\
=4.260\end{array}$ \\
\hline
\end{tabular}

industrial production. An increase of the industrial production in the branches which were directed at the production of finished goods in 2005-2014 was a positive factor in industrial development. Due to measures intended for localization of the production in the main economic fields and development of industrial cooperation, a volume of the consumption from the domestic market has been grown. Cooperation set with companies such as "MAN", "CLASS", "Toshiba", "Candy", "LG" and "Samsung" has played an important role in this regard.

Effects of industrial development indicators, \% [6,50]

Table 3

\begin{tabular}{|l|l|l|l|l|}
\hline \multicolumn{1}{|c|}{ Indicators } & \multicolumn{4}{|c|}{ Years } \\
\hline $\begin{array}{l}\text { Fuel and raw materials sectors contribution to the } \\
\text { industry } \\
\text { construction, cotton ginning) }\end{array}$ & 61.5 & 53.3 & 45.3 & 42.9 \\
\hline $\begin{array}{l}\text { Processing sector contribution to the industry } \\
\text { (Chemicals, machinery, light industry, food } \\
\text { processing) }\end{array}$ & 38.5 & 46.7 & 54.7 & 57.1 \\
$\begin{array}{l}\text { The contribution of sectors ensuring the } \\
\text { technological development of the economy on the } \\
\text { industry }\end{array}$ & 29.5 & 29.3 & 31.4 & 32.3 \\
\hline The contribution of in industry & 34.3 & 36.3 & 30.1 & 22.8 \\
\hline The growth rate of fuel sector & 102.6 & 103.3 & 103.9 & 103.2 \\
\hline The growth rate of manufacturing sector & 114.2 & 116.6 & 115.1 & 115.1 \\
\hline
\end{tabular}

The average annual growth in motor and metal recycling industries made up $120,4 \%$ and, in turn, it has caused the average growth in recycling industry to made up to $115,8 \%$. The average growth in food, chemistry, oil and light industries also made up high rates. The growth of diversification in the fields of power, fuel, ferrous and nonferrous, motor and light industries has influenced on the growth diversification rate in industry. While recycling industry made up $38,5 \%$ in general industry in 2005 , this indicator made up $57,1 \%$ in 2014 (table 3). Positive trends in the structure of industry have been observed in the sectors which supplies the technical development in economy (this indicator was $29,5 \%$ in 2005 and it was grown up to $32,3 \%$ in 2014). A volume of consumer goods production was grown up to $39,6 \%$ (2014). A stimulation of the domestic demand and improvement of living conditions of the population has impacted on the growth of this indicator. From 2005 to 2014, a production efficiency in industry was grown 1,4 times. The field in which the production efficiency has increased with the highest rate is motor industry and this indicator made up 3,3 times in 2014 than that of 2005. During the period of 2005-2014 the growth of a volume of industrial good production 2,2 times indicates that industrial companies were fully accommodated to conditions of a new market. In this regard, consumer goods production has grown with high rates. While fuel raw industry was grown 1,5 times in 2014 than that of 2005, this indicator made up 3,8 times in recycling industry.

The share of sectors in the industry $(\%)[5,50 ; 6,114]$

Table 4

\begin{tabular}{|c|c|c|c|c|c|c|c|c|c|c|c|c|}
\hline & હ્సి & ฮิ่ & 气ิે & 气̊ำ & ڤ్ & 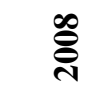 & 록 & $\overline{\bar{\pi}}$ & ิㅗำ & $\stackrel{m}{\bar{\pi}}$ & ت্ & 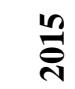 \\
\hline $\begin{array}{l}\text { Industry, } \\
\text { including }\end{array}$ & 100 & 100 & 100 & 100 & 100 & 100 & 100 & 100 & 100 & 100 & 100 & 100 \\
\hline electro energy & 8,5 & 8,1 & 9,1 & 11,3 & 10,0 & 8,6 & 8,4 & 8,0 & 7,7 & 7,1 & 7,1 & 7,4 \\
\hline fuel & 15,3 & 13,2 & 12,2 & 16,2 & 17,0 & 20,1 & 19,2 & 17,5 & 18,0 & 15,0 & 13,1 & 12,5 \\
\hline $\begin{array}{l}\text { heavy } \\
\text { metallurgy }\end{array}$ & 1,2 & 1,4 & 1,8 & 2,3 & 2,3 & 2,9 & 2,4 & 2,6 & 2,6 & 2,3 & 2,4 & 2,9 \\
\hline $\begin{array}{l}\text { non-ferrous } \\
\text { metals }\end{array}$ & 10,2 & 10,9 & 15,0 & 17,1 & 18,5 & 12,6 & 11,3 & 10,4 & 10,0 & 9,0 & 8,8 & 8,0 \\
\hline
\end{tabular}

ISPC Technology and Innovation, 


\section{Impact Factor:}

\begin{tabular}{lr|lr} 
ISRA $($ India) & $=\mathbf{1 . 3 4 4}$ & SIS (USA) & $=\mathbf{0 . 9 1 2}$ \\
ISI $($ Dubai, UAE) & $=\mathbf{0 . 8 2 9}$ & PИНЩ (Russia) $=\mathbf{0 . 2 3 4}$ \\
GIF (Australia) & $=\mathbf{0 . 5 6 4}$ & ESJI (KZ) & $=3.860$ \\
JIF & $=\mathbf{1 . 5 0 0}$ & SJIF $($ Morocco $)=\mathbf{2 . 0 3 1}$
\end{tabular}

\begin{tabular}{|l|l|l|l|l|l|l|l|l|l|l|l|l|}
\hline & & & & & & & & & & & & \\
\hline $\begin{array}{l}\text { Chemistry and } \\
\text { oil chemistry }\end{array}$ & 5,7 & 5,6 & 5,8 & 5,2 & 4,8 & 5,1 & 5,1 & 5,5 & 5,5 & 5,4 & 5,5 & 4,8 \\
\hline $\begin{array}{l}\text { Automobile } \\
\text { industry and } \\
\text { metalworking } \\
\text { industry }\end{array}$ & 9,9 & 11,2 & 12,3 & 13,0 & 13,8 & 16,2 & 16,2 & 16,1 & 17,5 & 18,8 & 19,7 & \\
\hline $\begin{array}{l}\text { Construction } \\
\text { materials }\end{array}$ & 5,4 & 5,2 & 4,1 & 3,6 & 4,2 & 4,9 & 5,0 & 5,3 & 5,5 & 6,5 & 6,1 & 5,1 \\
\hline $\begin{array}{l}\text { Wood and } \\
\text { paper industry }\end{array}$ & 1,4 & 1,3 & 1,2 & 0,9 & 0,8 & 1,0 & 1,1 & 1,1 & 1,3 & 1,4 & - & - \\
\hline Light industry & 19,1 & 20,0 & 19,7 & 16,6 & 14,6 & 12,9 & 13,4 & 13,5 & 12,9 & 13,2 & 14,0 & 16,2 \\
\hline Food industry & 13,3 & 12,6 & 12,3 & 8,2 & 8,9 & 10,6 & 12,6 & 14,0 & 13,2 & 15,7 & 16,0 & 20,2 \\
\hline others & 10,0 & 10,5 & 6,5 & 5,6 & 5,1 & 5,1 & 5,3 & 6,0 & 5,8 & 5,6 & 7,3 & 7,2 \\
\hline
\end{tabular}

The table given above indicates that power, fuel, motor, light and food industries, nonferrous metallurgy have an important place in the industrial sector. If we have a look at component changes in the sector in 2000-2014, then we will see that the part of power field in industry made up $7,1 \%$, fuel industry was decreased from $15,3 \%$ to $13,1 \%$, but it was grown at average by 5\% annually, fuel-power independence was obtained and recycling ability in the sector was increased. The part of motor industry was grown from $9,9 \%$ to $19,7 \%$ and the part of metallurgy was not changed. In turn, it shows that modern companies run productively. Although the part of chemistry, oil, paper and building materials industries in total industrial production was not almost changed, economic reforms in these fields too were undertaken (table 4).

Privatization of 127 companies by "Uzneftgaz" and 19 companies by "Uzkimyosanoat" indicates the development of these fields. During this period, high growth rates in the industrial sector was undertaken through a stimulation of the production of finished goods in motor, metal recycling, ferrous metallurgy, chemistry, light and food industries. In the production of goods of motor, metal recycling, chemistry, oil, building materials, power, ginning, hosiery, sewing, food, flour, grain, glass, white ware, medicine and printing industries could be achieved high growth rates.

As a result of an increase to use the industrial potential, a volume of the production of gas, power, coal, steel, cement, motor industries goods was grown. In this period, as a result of an increase of food goods production by the national industrial companies, import of tinned meat, clothes, cement, concrete and fireproof protective means was considerably decreased.

High results were achieved in the fields such as motor, chemistry, oil, food and building materials industries. An intensive growth of motor industry was observed. It is considered as a result of the growth of a physical volume of motor production. Production of cars that are in high demand in both international and domestic markets was grown: large investment projects on the production of new models of automobiles in the class of "Optima", "Gentra", "Cobalt" and "Spark" besides "Matiz", "Damas", "Nexia" and "Lacetti" were realized.

Founding of a new complex for the production of 3,000 trucks and trailers per year in Samarkand region (of which cost is 69,38 million dollar), founding of a company for the production of 900,000 wheels and 123,000 undercarriages per year for automobiles of "General Motors Uzbekistan" CC in Andijan region, founding of a company for the production of 120,000 kits of welding parts per year for abovementioned automobiles in Fergana city as well as founding of companies for the production of car seats, windows, accumulators, jacks, bumpers, plastic parts, door panels, radiators, ventilation and heating systems have played an important role in stabilization of the industrial goods production as well as in providing of their competitive ability in international markets.

Growth rates of electrical engineering and motor industry of national economy were increased. The part of freezers, refrigerators, TV sets and other goods in the volume of electrical engineering field has been saved in low rates. Furthermore, the production of transformers and cable goods was considerably grown, the elevator production was recovered.

Although a production of spare parts in motor industry of national economy, machineries for light and textile industries, tractor trailers, new types of trailer equipment for machineries of national economy could be considerably grown, but in the production of tractors high results were not achieved. Stable demand for ferrous and nonferrous metals in the international market, necessity of replenishment of the domestic market with the national goods and development of localized industry were important factors for the growth that gained in the metallurgy complex. Industrial production of goods in fields of the chemistry complex also is being developed stably. Besides, wide production of goods of oil and chemistry industry, which has a "narrow place" in the structure of the main chemistry industry as well 
as production of potash fertilizers and chemistry means for protection of plants, has developed mainly.

Approximation of the rate of inner prices to the rate of import prices in condition of the growth of demand, which has payment ability, has been one of the factors of the development of stable dynamics in the development of food industry. A volume of production of sugar, flour and flour goods was decreased. Stable demand in the domestic market for providing of industrial production and founding of social infrastructure objects as well as the growth of export rate was the main factor that have caused the growth of building materials production. The part of building materials industry in industrial production of the country included a low rate and made up 6,1\% (2014). Some factors, such as the growth of prices, a conjecture of inner and outer demands have impacted on the development of the fields.

In our country, the following are the main factors of the development of industry in last periods:

Realization of the target programs;

Development of the infrastructure (water, gas, power industry, transport and others);

$\square$ Founding of new companies in the field of light industry and adoption of production of finished goods;

Founding of new companies in the field of recycling of leather raw materials and adoption of production of new goods;

Founding of new companies in the field of recycling of agrarian goods and providing of the market with the national goods;

Production of consumer goods and fully providing of markets with these goods;

$\square$ Development of building materials industry;

Increase of importance of bank credits in the development of industry;

$\square$ Increase of parts of joint stock companies in the development of industry;

$\square$ Recycling of the national raw materials;

$\square$ Wide use of privileges and preferences that created on the localization program, international industrial fair and exchange of cooperation;

Increase of export rate of produced goods and help small companies to export their goods [7, 16].

The growth rate of industry in the different regions made up different percentage. The growth of industrial goods production made up the biggest percentage $(4,68 \%)$ in Tashkent in 2014. Besides, in Samarkand, Andijan, Khorazm and Namangan regions also, this indicator made up considerable percentage. The main part of investments also was directed at these regions. During this period, large objects, such as Kungirot Company for production of bicarbonate and "Tupalang" hydroelectric power station, production of coil of copper and its floating in "Uzmetkombinat" APO, the first stage of utilization of gas in "Kukdumalak" joint stock Company were put into service, building of a gasfractionation plant in Fergana Oil recycling factory and of Gazli-sarimay gas delivery system was finished, a project of investments in textile industry was finished and realization of large projects of investments in the main fields of industry was started.

As a result of measures on the stimulation of production of consumer goods and supporting of business, production of refrigerators, freezers, washing machines, TV sets, soft drinks, juice, sugar, macaroni foods, vegetable oil, carpets and white wares was grown. The growth of industrial goods production was carried out on account of detailed thought policy that carried out sequentially in condition of systematic market economy, involving of foreign investments, deep systematic changes in economy, modernization and upgrade of industrial production, founding of new fields and companies intended for export and development of private business, not on account of increase of extensive factors for economic development of Uzbekistan.

High developed fields, such as motor and chemistry industries are considered as leading links of modern economy. These fields have played a role of the main generator of economy. Development of leading fields is based on potential industrial production and a technic, human resources and scientific base. Wide use of new technics and technologies, increase of production of goods safe for the ozone layer, realization of new technology of nitrobenzene gaining for aniline and lacquer-paint industry, production of medicine means that allow the efficiently growth of industrial production, decrease of industrial wastes, use of industrial wastes efficiently, financing of the main branches, complex implementation of mineral and hydro carbonic raw materials in the development of chemistry and oil industries are very important.

\section{Conclusion}

As a conclusion, our country has an opportunity to use the efficiency of international economic relations in realization of the industrialization process. To use this opportunity and comforts efficiently and in due time allows to increase the efficiency of industrial production. At that, some factors, such as an acceleration of the modernization process and improvement their financial status is important for supply of implementation of measures on an increase of the production rate of competitive able industrial goods, efficient use service of institutions that intended for informing the public qualities of industrial goods, development of relations between industrial production and trade companies and industrial and recycling companies to produce modern and competitive able goods. 


\begin{tabular}{l|lr|ll|ll} 
& ISRA (India) & $=\mathbf{1 . 3 4 4}$ & SIS (USA) & $=\mathbf{0 . 9 1 2}$ & ICV (Poland) & $=\mathbf{6 . 6 3 0}$ \\
Impact Factor: & ISI (Dubai, UAE) $=\mathbf{0 . 8 2 9}$ & PUHL (Russia) $=\mathbf{0 . 2 3 4}$ & PIF (India) & $=\mathbf{1 . 9 4 0}$ \\
& GIIF (Australia) & $=\mathbf{0 . 5 6 4}$ & ESJI (KZ) & $=3.860$ & IBI (India) & $=\mathbf{4 . 2 6 0}$ \\
& JIF & $=\mathbf{1 . 5 0 0}$ & SJIF (Morocco) & $=2.031$ & & \\
\hline
\end{tabular}

\section{References:}

1. Karimov I.A. (1996) Bizdan ozod va obod Vatan qolsin. V.2. - T.: Uzbekistan.

2. (2014) The quick typograhpy and service department of the State Statistical Committee of the Republic of Uzbekistan. - p. 212.

3. (2015) A speech of the first President of the Republic of Uzbekistan, Islam Karimov, at the meeting of the Cabinet of Ministers dedicated to the results of social and economic development of our country in 2015 as well as to the highest directions of the economic program.

4. (2016) A textbook on the study of a speech of the first President of the Republic of Uzbekistan, Islam Karimov, "Our main goal is to sharply deepen the reforms and structural transformations in our economy, to open up opportunities for private ownership, small business and entrepreneurship". - T.: Ma'naviyat, 2016.
5. (2010) An almanac Uzbekistan on information of the State Statistical Committee of the Republic of Uzbekistan 2010. - T.: Niso poligraf.

6. (2015) Tendensii sotsialno-ekonomicheskogo razvitiya Uzbekistana (2005-2014) edited by D. Sc. on economy A.M. Sadikov/Tashkent. IFMR.

7. (2012) A textbook on the study of a speech of the first President of the Republic of Uzbekistan, Islam Karimov, at the meeting of the Cabinet of Ministers of the Republic of Uzbekistan devoted to the main results of of 2011 and the highest directions of the social and economic development of Uzbekistan in 2012, on the theme of " 2012 will become a year for raising of the development of our country to a new stage". - T.: Iqtisodiyot. 